\title{
Possible Aquaculture Development in Nigeria: Evidence for Commercial Prospects
}

\author{
Amosu Albert Oluwatobi ${ }^{1,2}$, Hammed Ayofe Mutalib ${ }^{3}$, Togunde Kasaliyu Adeniyi ${ }^{2}$, Joseph Olufemi Olabode ${ }^{2}$ \\ and Adekoya Adeyemi ${ }^{2}$ \\ 1. Department of Biodiversity and Conservation Biology, Faculty of Natural Sciences, University of the Western Cape, Private Bag \\ X17, Bellville 7535, South Africa
}

2. Department of Agricultural Science, School of Vocational and Technical Education, Adeniran Ogunsanya College of Education, Otto/Ijanikin, PMB 007 Festac Town, Lagos, Nigeria

3. Department of Fisheries, Faculty of Science, Lagos State University, P.O. Box 0001, LASU Post Office, Ojo, Lagos, Nigeria

\begin{abstract}
The cultivation of desirable aquatic organisms is becoming increasingly important as one of the fastest-growing agro-industrial activities in the world. Nigeria, over the years, practised traditional methods of aquaculture in tidal pools and floodplains of inland waters. Recently, the coastal region has been the focus of aquaculture development with introduction of cage culture system. Nigeria is one of the top aquaculture producers in Africa with numerous opportunities for large-scale production, and $80 \%$ of production is from small-scale farmers who involve in brackish and freshwater cultivation, except mariculture which has several setbacks. Nigeria is yet to show feasible interest in non-fed aquaculture (macroalgae) which is among the world's most efficient mass producer of proteins and other products. Constraints to production in the industry have been identified, while the prospects can be achieved by expanding aquaculture zones, enhancing management practices of production systems and improving product quality with the resultant creation of jobs, regular income and investment, etc.. This paper explores the status of aquaculture in Nigeria, and the components and the systems of commercial aquaculture were elucidated.
\end{abstract}

Key words: Aquaculture, commercial fish farming, macroalgae, mariculture, industry.

\section{Introduction}

Aquaculture productions have increased in the last decade. Presently, world food fish production of aquaculture has expanded by almost 12 times, at an average annual rate of $8.8 \%$ [1-3]. Over 300 aquatic species are farmed worldwide for production in a variety of facilities of varying input intensities and technological sophistication, using fresh, brackish and marine water [4]. The most prominent species includes finfish, crustaceans and mollusks, which are commercially cultured with a relevant production in some country. Global production of farmed food fish was 32.4 million metric tonnes in 2000 up by $7.5 \%$ to 55.7 million metric tonnes in 2009 and 60 million

Corresponding author: Amosu Albert Oluwatobi, Ph.D., research fields: fisheries and environment. metric tonnes in 2010 with a total value of US \$119 billion [3]. Aquaculture remains one of the fastest-growing agro-industrial activities in the last four decades and is projected to outpace population growth. In the next decade, total output from both capture and aquaculture is envisaged to exceed that of other livestock produce [2, 3]. Asia is the highest aquaculture producer with about $90 \%$; the largest quantities are from China, while Africa and Latin America produce less than 5\% [3, 4]. Currently, the African continent accounts for less than $1 \%$ of the annual total global aquaculture production [3, 5], and the vast majority of Africa's aquaculture is in fresh water. There are many setbacks for the development of aquaculture to meet the global food security and economic growth, as well as to reduce the pressure on wild harvested fisheries stock. 
Fish is currently the cheapest source of animal protein consumed by the average Nigerian and it accounted for about $50 \%$ of total protein intake [6]. Fish supply in Nigeria is mainly from the capture sector, especially the coastal and inland artisanal fisheries. The sector contributes about $85 \%$ of total domestic production [5, 7]. Nigeria imports over 700,000 metric tonnes of fish per annum, and annual deficit of about 0.5 million metric tonnes still exist (Table 1). Aquaculture has recently been recognized as an alternative means of increasing domestic fish production. It is estimated to have the potential of overtaking capture fisheries in future. Aquaculture in Nigeria is receiving a wide participation as a result of the progressive development in most parts of the country. The total current aquaculture production has leaped from 50,000 metric tonnes in 2005 to 85,000 metric tonnes [7], and demand is expected to continue to grow with anticipated population growth. As at 2004, there are over 2,600 fish farms and 215 feeds mills in the country with most of them located in the southern part of Nigeria, and fish feeds account for about $60 \%$ of the input cost production in intensive system in Nigeria [6, 8]. Aquaculture activities is concentrated in the coastal areas, but may at the long term be constrained due to competition by many industrial and domestic users [9]. This paper intends to elucidate the Nigeria's aquaculture potentials with a view to providing intervention recommendations on prospects for aquaculture development.

Table 1 Projected population and fish demand/supply in 2000-2025.

\begin{tabular}{|c|c|c|c|c|}
\hline Year & $\begin{array}{l}\text { Population } \\
\text { (million) }\end{array}$ & $\begin{array}{l}\begin{array}{l}\text { Fish demand } \\
\text { (million tonnes) }\end{array} \\
\end{array}$ & $\begin{array}{l}\text { Fish supply in domestic production } \\
\text { (million tonnes) }\end{array}$ & $\begin{array}{l}\text { Short fall } \\
\text { (million tonnes) }\end{array}$ \\
\hline 2000 & 114.40 & 0.87 & 0.53 & 0.34 \\
\hline 2001 & 117.60 & 0.89 & 0.57 & 0.32 \\
\hline 2002 & 121.00 & 0.92 & 0.61 & 0.31 \\
\hline 2003 & 124.40 & 0.95 & 0.65 & 0.30 \\
\hline 2004 & 127.90 & 0.97 & 0.69 & 0.28 \\
\hline 2005 & 131.50 & 1.00 & 0.73 & 0.27 \\
\hline 2006 & 135.20 & 1.03 & 0.77 & 0.26 \\
\hline 2007 & 139.10 & 1.06 & 0.81 & 0.25 \\
\hline 2008 & 143.00 & 1.09 & 0.85 & 0.24 \\
\hline 2009 & 147.10 & 1.12 & 0.89 & 0.23 \\
\hline 2010 & 151.20 & 1.15 & 0.93 & 0.22 \\
\hline 2011 & 155.50 & 1.18 & 0.96 & 0.21 \\
\hline 2012 & 159.90 & 1.22 & 1.00 & 0.22 \\
\hline 2013 & 164.40 & 1.25 & 1.04 & 0.21 \\
\hline 2014 & 169.10 & 1.29 & 1.08 & 0.21 \\
\hline 2015 & 173.90 & 1.32 & 1.12 & 0.20 \\
\hline 2016 & 178.80 & 1.36 & 1.16 & 0.20 \\
\hline 2017 & 183.30 & 1.39 & 1.20 & 0.19 \\
\hline 2018 & 189.00 & 1.44 & 1.24 & 0.20 \\
\hline 2019 & 194.40 & 1.48 & 1.28 & 0.20 \\
\hline 2020 & 199.90 & 1.52 & 1.32 & 0.20 \\
\hline 2021 & 205.60 & 1.56 & 1.36 & 0.20 \\
\hline 2022 & 211.40 & 1.61 & 1.40 & 0.21 \\
\hline 2023 & 217.40 & 1.65 & 1.44 & 0.21 \\
\hline 2024 & 223.50 & 1.70 & 1.48 & 0.22 \\
\hline 2025 & 229.80 & 1.75 & 1.52 & 0.23 \\
\hline
\end{tabular}

Source: FAO 2000 [10]. 


\section{The Systems of Commercial Aquaculture in Nigeria}

\subsection{Freshwater Aquaculture}

In freshwater fish culture, water salinity based on dissolved salts in parts per thousand (ppt) is < 0.5 ppt. Some cultivable fish species cultured in Nigeria, which are capable of thriving well in the fresh water environment, include: Clarias gariepinus, Clarias lazera, Heterobranchus bidorsalis, Heteroclarias, Tilapia sp., Tilapia mariae, Oreochromis niloticus, Oreochromis mossambicus, Sarotherodon galilaeaus, Sarotherodon melanotheron, Tilapia zilli, Tilapia guinensis, Hereterotis niloticus, Chrysichthys nigrodigitatus and Cyprinus carpio, etc.. However, there has been three major freshwater fish genus farmed in Nigeria, namely, Clarias, Tilapia and Heterotis [11]. Apart from the earthen ponds, tank cultivation is characterized by high yield, with its efficiency dependent on aeration, water quality and flow rate, etc. [11-13]. Tanks are usually made from treated wood, concrete or PVC plastic and fibreglass, with capacities ranging from a few hundred litres to several thousand cubic metres [11]. Even though this cultivation technique is a capitally intensive venture, the input is usually relatively quickly recovered if the system is well managed [14]. The Nigeria freshwater aquaculture technology is developing, still undergoing research and has gained steady recognition, due to the increasing demand for cheap source of protein and livelihood that has seen the need for sustainable production [15].

\subsection{Brackish-Water Aquaculture}

Naturally, brackish water environment is characterised with the salinity of the water fluctuating widely from negligible to 30 ppt or $30 \%$, depending on the phase or phases of the tide and volume of fresh water discharged through the river into the sea. These phenomenons make it more turbid with influx of nutrients and fertile to accommodate good numbers of acclimatized fresh and brackish water fish species, either for breeding or feeding. Brackish water contains 0.5-30 g of salt per litre or more often expressed as 0.5-30 ppt. Brackish water fish farming is a system of aquaculture that focuses on the production of quality fin and shell fish that are found in the creeks, lagoons and estuaries through rational rearing. The region is naturally endowed with a long coast line bordering the Atlantic Ocean and an extensive network of inland river systems [15]. Research estimated that there are about 729,000 ha of saline mangrove swamp suitable for development of commercial fish farming [16]. The significant aquatic flora around this complex estuarine/lagoon system in Nigeria is characterized by stilt-rooted trees with dense undergrowth of shrubs, and by raffia palms (Raphia sudanica) and oil palms (Elaeis guineensis). The dominant plant species in the swampy areas of the lagoon include Rhizophora racemosa and Avicennia nitida. The principle of brackish water fish farming mainly lies in allowing the tidal water to enter into the pond and flood it to the optimal depth as may be required by the cultured fish, and also allowing the outflow of the water during low-tide to a minimum tolerable depth [17]. Many fin and shell fish species are abundant in brackish water area, which can be cultured with the minimal capital input in most of the coastal communities. According to Deekae et al. [18], most of the shell fish production is yet to be developed in commercial scales, as obtained in other fish producing countries in Asian, like Japan, China, Indonesia, Thailand and Philippines among others. Hence, there is the need to focus more on these areas, in order to enhance food security and employment opportunities for people living in the region.

\subsection{Marine-Water Aquaculture}

In marine-water aquaculture, the water chemistry requirement for salinity based on dissolved salts is 0.30-50 ppt. Fish farming in this zone will have some major constraints because of the choppy conditions and heavy rainfall which occur in the coastal belt. The 
teeming population of engineers of various disciplines, fisheries researchers (biologists and ecologists), seasoned aquaculturists, technologists, technicians and thousands of kilometres of low lying coastline containing billion cubic metres of marine water are mariculture great potentials [15]. The continental shelf is narrow, extending for only about $15 \mathrm{~km}$ in the western area and ranges from $60 \mathrm{~km}$ to $80 \mathrm{~km}$ in the eastern province. The culture of marine fish species can be a possibility in Nigeria, if all the available potentials can be harnessed. The five major constraints of mariculture in Nigeria are domiciled in the characteristic nature of the coastal area (Fig. 1) and can be summaries as follows:

(1) Nigeria coastal areas, like other developed coastal towns in the world, are densely populated with heavy commercial and industrial activities, which results in pollution;

(2) Inshore and offshore oil exploration usually lead to oil spill with a resultant effect on water chemistry and fish kill;

(3) The Nigeria coastal water from Lagos to Calabar region is very shallow, while coastal mariculture (earthen) will require about $200 \mathrm{~m}$ depth above;

(4) Under-develop technology for sustainable aquaculture production in land base industrial mariculture;

(5) Lack of political-will on the part of government to have preferred crude oil to mariculture in the coastal area due to the dependent nature of the Nigeria mono-economy.

One of the major steps in the bid to establish this technology should involve carrying out more biological and ecological studies and review of literature to ascertain life cycle of culturable marine fish species in Nigerian marine waters. It is important to use package propagation procedures, care of larvae, fry, fingerlings and post juveniles to table size, while viable and genetically diverse brood stocks would be sustained in banks. Best method of live seed transport per fish species, as well as appropriate feed must be formulated for each stage of the fish species, that is, for larvae, fry, fingerling and adults. Several other constraints have prolonged the development of the mariculture industry in Nigeria, and these can be

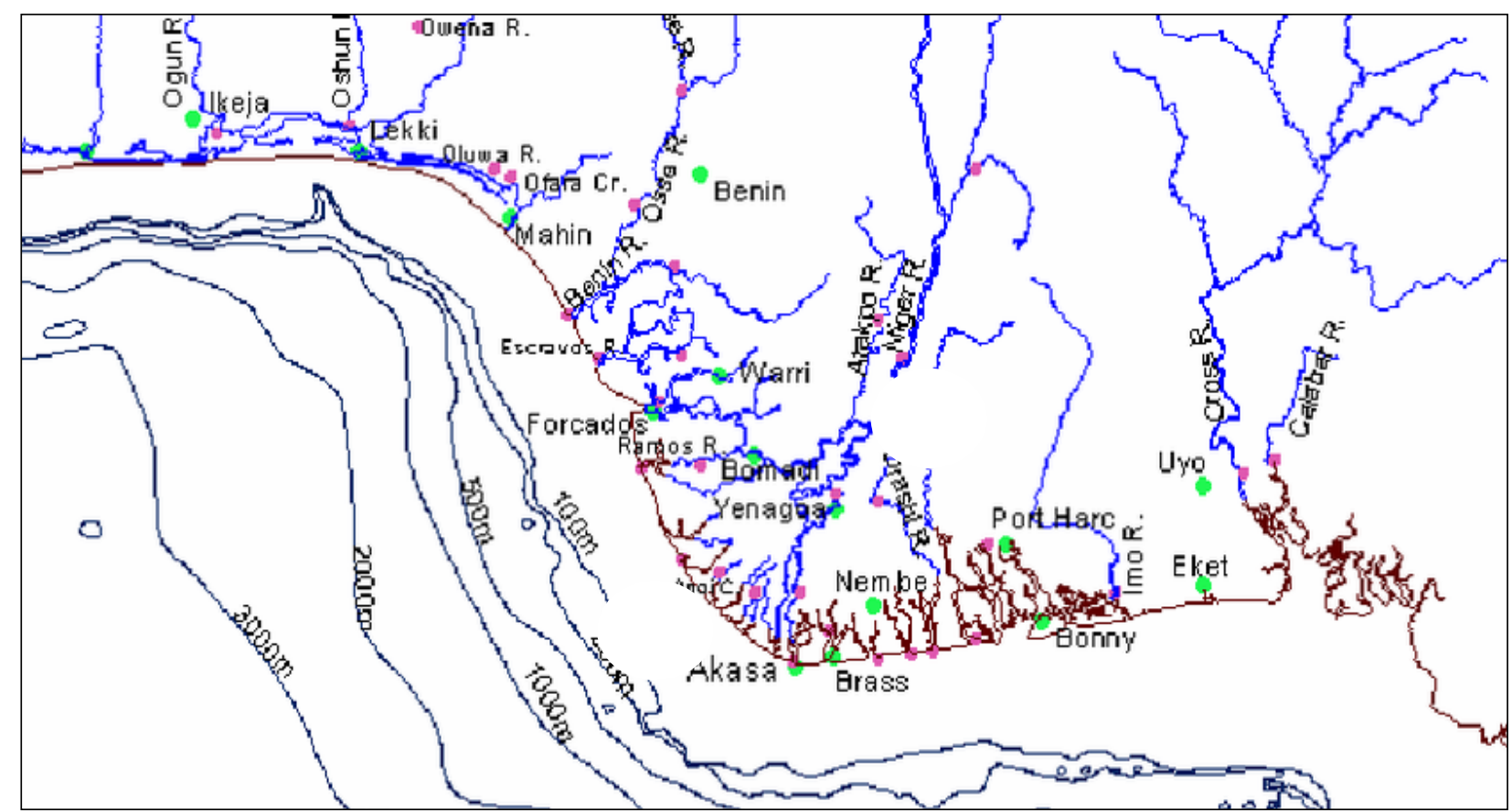

Fig. 1 The Nigeria coastal area. 
summarized as: weak economies, poor aquaculture development policies, inappropriate technologies, weak extension services, weak impact of research institutions, inadequate information management systems, limited coordination between research and production sectors, scanty reliable production statistics, the high value/cost of coastal land and the associated competition for this land from other coastal industries [19].

\section{Cultivable Fish Species in Nigeria}

Of the over 210 species of fishes in Nigeria water bodies, little fraction of them are receiving cultivation attention from fish farmers. The production of freshwater fish culture is widely accepted and encouraged (contributing between 0.65-1.2 million tonnes of fish annually from inland fresh water alone), followed by brackish water aquaculture, while mariculture is clearly not popular (Table 2) [11]. Some conventional culturable fish species in Nigeria includes: Clarias gariepinus, Clarias lazera, Heterobranchus sp., Heteroclarias, Tilapia, Oreochromis niloticus, Sarotherodon galilaeaus, Sarotherodon melonoplura, Tilapia zillii, Tilapia guineansis, Chrysichthys nigrodigitatus, Cyprinus Carpio, etc.. They are proven to be of higher consumer preference due to their high premium and food productivity, as they have been cultured widely in the tropics for food and ornamental purposes [11-13]. The unconventional cultured ones with low preference probably due to lack of promotion or identification are: $H$. niloticus, G. niloticus, $L$. niloticus, etc., as the following:

(1) H. niloticus: rapid growth, breeds in captivity, availability of wild fingerlings and brood stocks, mean standard length (SL) of $100 \mathrm{~cm}$, mean total weight (TW) of $10.2 \mathrm{~kg}$, mean fecundity rate (FR) of 4,000-6,000 eggs, good for polyculture and cage culture system as well sport fishing;

(2) L. niloticus: rapid growth, high premium, breeds in captivity, grows up to $200 \mathrm{~cm}$ (maximum length),
200 kg (TW), 3,000,000-15,000,000 eggs (FR), good for polyculture and cage culture system;

(3) G. niloticus: rapid growth, high premium, tasteful, seasonal availability of wild growers, grows up to $193 \mathrm{~cm}$ (SL), $200 \mathrm{~kg}$ (TW), 6,000-9,000 eggs (FR), good for polyculture;

(4) P. obscura: rapid growth, tasteful, medicinal properties, seasonal availability of wild growers, grows up to $54.0 \mathrm{~cm}$ (maximum length), $1.0 \mathrm{~kg}$ (TW) in 4-5 months, 126-1,580 oocytes (FR), good for polyculture and cage culture system;

(5) L. coubie: tasteful, seasonal availability of wild growers, grows up to $22.2 \mathrm{~cm}$ (SL), $619 \mathrm{~g}$ (TW) 10,411-24,143 eggs (FR), good for polyculture and cage culture system [11-14, 20-23].

\section{Seaweed/Macroalgae and Its Potentials in Nigeria}

Macroalgae is currently the most significant aquatic plant that has contributed to the development of fisheries and the aquaculture industry [24]. Nigeria is endowed with about 79 species of seaweed, and the coastlines are characterized by sandy beaches and extensive mangroves, deltas, estuaries and lagoons with correspondingly low algal diversity [25]. Recent researches by Amosu et al. [16], Fakoya et al. [26] and Abowei and Tawari [27] have shown the potential of macroalgae resources for exploitation, culture and utilization for Nigeria, but as yet, no targeted commercial harvesting and cultivation has commenced. The cultivation methods of varies depend on the macroalgae species, which includes open water cultivation, land-based or semi-closed cultivation, pond cultivation, tank culture and raceways, spray cultivation systems. However, the on-land integrated culture units flow through integrated multi-trophic aquaculture (IMTA), and paddle-wheel raceways (Fig. 2) are now widely viewed as the preferred method of cultivating the main species of macroalgae [16].

Macroalgae have been called the medical food of the 21st century [28]. According to the World Health 
Table 2 Summary of data on aquaculture species of finfish and shellfish in Nigeria (modified after Refs. [11, 17, 20-23]).

\begin{tabular}{|c|c|c|c|c|c|}
\hline Species & $\begin{array}{l}\text { Popularity with } \\
\text { consumers }\end{array}$ & $\begin{array}{l}\text { Availability of } \\
\text { seeds for stocking }\end{array}$ & Known feeding habits & $\begin{array}{l}\text { Salinity } \\
\text { tolerance (ppt) }\end{array}$ & Remarks \\
\hline $\begin{array}{l}\text { T. rendalli } \\
\text { T. nilotica } \\
\text { T. galilaea } \\
\text { T. zillii } \\
\text { O. niloticus } \\
\text { S. melanotheron } \\
\text { O. mossambicus } \\
\end{array}$ & Average & $\begin{array}{l}\text { Year round and } \\
\text { adequate }\end{array}$ & $\begin{array}{l}\text { Algae, phytoplankton, } \\
\text { detritus, various } \\
\text { supplementary feeds }\end{array}$ & $\begin{array}{l}0 \text {-26 or more } \\
\text { depending on } \\
\text { species }\end{array}$ & $\begin{array}{l}\text { Hardy and good as standby species } \\
\text { in absence of more popular species } \\
\text { for stocking; } \\
\text { Disadvantage is uncontrolled } \\
\text { breeding. }\end{array}$ \\
\hline C. nigrodigitatus & Very good & $\begin{array}{l}\text { Year round but } \\
\text { inadequate }\end{array}$ & $\begin{array}{l}\text { Bivalves as } \\
\text { supplementary feed; } \\
\text { groundnut cake and } \\
\text { palm kernel cake as } \\
\text { essential food } \\
\end{array}$ & $0-26$ & $\begin{array}{l}\text { Hardy, but supplementary feed } \\
\text { absolutely necessary; } \\
\text { Has grown well with tilapias and } \\
\text { mullets. }\end{array}$ \\
\hline $\begin{array}{l}\text { L. falcipinnis } \\
\text { M. bananensis } \\
\text { L. grandisquamis } \\
\text { L. dumerilii } \\
\text { M. monodii } \\
\text { M. curema } \\
\end{array}$ & Good & $\begin{array}{l}\text { Year round and } \\
\text { adequate }\end{array}$ & $\begin{array}{l}\text { Detritus, } \\
\text { phytoplankton, algae, } \\
\text { supplementary feeds }\end{array}$ & $0-35$ & $\begin{array}{l}\text { Has given good results in brackish } \\
\text { water; } \\
\text { Experiments in fresh water under } \\
\text { way. }\end{array}$ \\
\hline $\begin{array}{l}\text { C. lazera } \\
\text { C. gariepinus }\end{array}$ & Very good & $\begin{array}{l}\text { Year round but } \\
\text { inadequate }\end{array}$ & $\begin{array}{l}\text { Omnivorous, } \\
\text { supplementary feeds }\end{array}$ & $0-25$ & $\begin{array}{l}\text { Can be stocked very densely if } \\
\text { supplementary feed is given; } \\
\text { Now cultured with tilapias. }\end{array}$ \\
\hline $\begin{array}{l}\text { H. niloticus } \\
\text { Parachanna sp. }\end{array}$ & Low & $\begin{array}{l}\text { Seasonal and } \\
\text { inadequate }\end{array}$ & $\begin{array}{l}\text { Phytoplankton and } \\
\text { zooplankton }\end{array}$ & $\begin{array}{l}\text { Freshwater } \\
\text { only }\end{array}$ & $\begin{array}{l}\text { Small sizes favoured; } \\
\text { Larger sizes said to be of lower taste. }\end{array}$ \\
\hline $\begin{array}{l}\text { E. fimbriata } \\
\text { (Bonga) }\end{array}$ & Good & Seasonal & Phytoplankton & $0-35$ & $\begin{array}{l}\text { Comes into ponds with the tide; } \\
\text { Appears to be sensitive to oxygen } \\
\text { deficiency; } \\
\text { Does not keep long once out of water. }\end{array}$ \\
\hline P. durarum & Very good & Seasonal & $\begin{array}{l}\text { Detritus of both plant } \\
\text { and animal origin }\end{array}$ & $0.5-35$ & $\begin{array}{l}\text { Comes into ponds with the tide; } \\
\text { Delicate and limbs easily damaged; } \\
\text { Has grown to about } 20 \mathrm{~g} \text { in ponds. }\end{array}$ \\
\hline $\begin{array}{l}\text { Macrobrachium } \\
\text { spp. }\end{array}$ & Very good & Seasonal & $\begin{array}{l}\text { Detritus of both animal } \\
\text { and plant origin }\end{array}$ & $\begin{array}{l}\text { Fresh to about } \\
10\end{array}$ & $\begin{array}{l}\text { Caught in abundance in certain areas } \\
\text { of the country. }\end{array}$ \\
\hline L. niloticus & Very good & Scarce & Predatory & $\begin{array}{l}\text { Fresh water } \\
\text { only }\end{array}$ & $\begin{array}{l}\text { Good predator species for tilapias, } \\
\text { but preys on carps also; } \\
\text { Fast growth. }\end{array}$ \\
\hline H. fasciatus & Low & Adequate & Predatory & $0-26$ & $\begin{array}{l}\text { Good predator species for tilapias; } \\
\text { Does not grow beyond about } 20 \mathrm{~cm} \text {; } \\
\text { When grown with large carps, feeds } \\
\text { on tilapia fry and fingerlings only. }\end{array}$ \\
\hline $\begin{array}{l}\text { L. apodus } \\
\text { L. agennes } \\
\end{array}$ & Good & Inadequate & Predatory & $1-32$ & $\begin{array}{l}\text { Good predator species for tilapias in } \\
\text { brackish-water ponds. }\end{array}$ \\
\hline G. niloticus & Good & Inadequate & Predatory & $\begin{array}{l}\text { Fresh water } \\
\text { only }\end{array}$ & $\begin{array}{l}\text { Good predator for tilapias. Fast } \\
\text { growth. }\end{array}$ \\
\hline E. lacerta & Low & Inadequate & Predatory & $1-26$ & $\begin{array}{l}\text { Comes into ponds with the tide; } \\
\text { Delicate and sensitive to oxygen } \\
\text { deficiency; } \\
\text { Does not keep long out of water. }\end{array}$ \\
\hline C. gasar & Good & $\begin{array}{l}\text { Almost throughout } \\
\text { the year }\end{array}$ & Phytoplankton & $2-32$ & $\begin{array}{l}\text { Spat settles better on hard timber } \\
\text { than old oyster shells or asbestos; } \\
\text { Better settlement in the shade than in } \\
\text { open areas; } \\
\text { Settlement more abundant in depths } \\
\text { about } 30-100 \text { cm from water surface; } \\
\text { Available all along the coastline in } \\
\text { the brackish-water areas; } \\
\text { Can grow to about } 8 \text { g (wet meat) in } \\
\text { one year under natural conditions. }\end{array}$ \\
\hline
\end{tabular}


(Table 2 continued)

\begin{tabular}{|c|c|c|c|c|c|}
\hline Species & $\begin{array}{l}\text { Popularity with } \\
\text { consumers }\end{array}$ & $\begin{array}{l}\text { Availability of } \\
\text { seeds for stocking }\end{array}$ & Known feeding habits & $\begin{array}{l}\text { Salinity } \\
\text { tolerance (ppt) }\end{array}$ & Remarks \\
\hline H. bidorsalis & Good & Seasonal & Omnivorous & Fresh water & $\begin{array}{l}\text { Responds well to fertilizer and } \\
\text { supplementary feeding. }\end{array}$ \\
\hline D. engycephalus & Good & Seasonal & Herbivorous & Fresh water & $\begin{array}{l}\text { Some ponds are noted for excess } \\
\text { grass and weeds; } \\
\text { These species are suspected to keep } \\
\text { weeds under control. }\end{array}$ \\
\hline $\begin{array}{l}\text { D. brevipinis } \\
\text { D. rostratus }\end{array}$ & Good & Seasonal & Herbivorous & Fresh water & - \\
\hline M. electricus & Good & Seasonal & Predator & Fresh water & $\begin{array}{l}\text { Good predator species for excess } \\
\text { tilapias in ponds. }\end{array}$ \\
\hline $\begin{array}{l}\text { M. atlanticus } \\
\text { P. jubelini }\end{array}$ & Good & Seasonal & Predator & $5-30$ & $\begin{array}{l}\text { Comes into pond with tide; } \\
\text { Good predator species for excess } \\
\text { tilapias in brackish-water ponds. }\end{array}$ \\
\hline
\end{tabular}

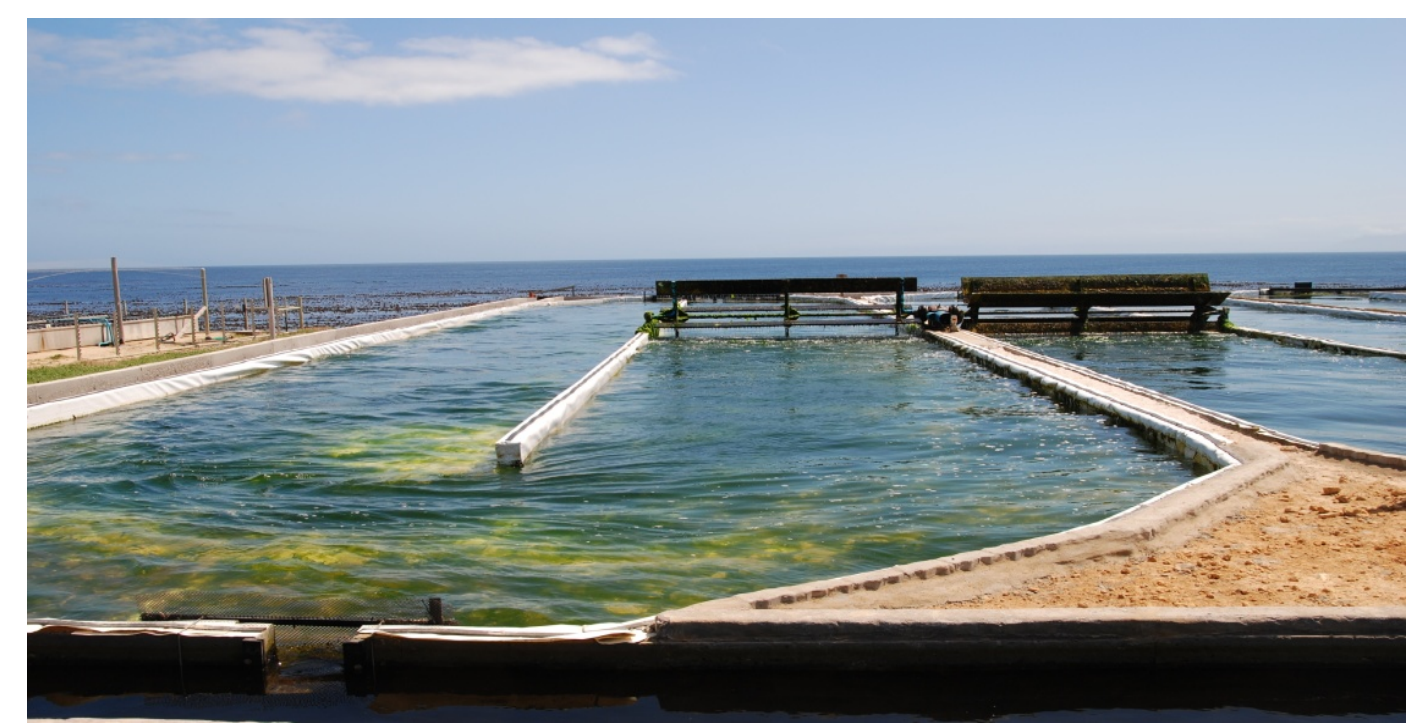

Fig. 2 Flow-through, paddle-wheel raceways for growing macroalgae.

Source: Dr. Deborah Vivienne Robertson-Andersson.

Organization (WHO), macroalgae are among the healthiest foods on the planet, as they contain vitamins, over 90 minerals and many antioxidants [1]. Most of this production is for human consumption either directly or indirectly, also these have been used commercially as feedstock for phycocolloid production, as well as the production of plant-growth stimulants used in the agricultural sector [29-31]. It has been used in the manufacture of pharmaceuticals and cosmetic creams [32]. This important marine resource has recently been emphasized due to the increasing demand for them as medicinal products, like anthelminthic, antibiotics, antifungal and antiviral, antitumour and antioxidant products, blocking and lowering of HIV/AIDS transmission and treatment of cancer patients [26, 33-38]. Seaweed can remove excess nutrients and major metallic pollutants from industrial and agricultural effluent, thus reducing coastal eutrophication [39, 40]. Research findings have further proven that biotransformation of seaweed to liquefied petroleum gas (LPG) is viable and economically feasible as clean fuel [41, 42]. Seaweed also has the potential to be a successful fin and shellfish feed, particularly if the diets including macroalgae grown with enriched nutrient are good substitutes for protein in formulated commercial feeds [35, 43, 44]. Additional benefits from seaweed farming activities include bioremediation, ocean de-acidification, and capturing of atmospheric and dissolved $\mathrm{CO}_{2}$ during growth to assist in climate change mitigation. 


\section{External/Internal Pressure on Aquaculture}

Natural, biological and economic hazards have increased in intensity and frequency in this decade. The African region has reeled from natural hazards that have included flooding, drought and the global financial crisis. Nigeria has the classical case of the destruction of fisheries and severe impacts on present and future aquaculture development by a factor external to the sector - the fate of the coastal water. Red and green tides and eutrophication have occasionally affected coastal aquaculture in Nigeria. The immediate effect of these natural and biological disasters on aquaculture is destruction of physical facilities, natural resources and damage to stock or reduction in value of harvests and loss of capital investments (Table 3). They have not led to the abandonment of farms, but have setback in growth. Nigeria government, like most African government, usually fails to give compensation for damage to crops and infrastructure from catastrophic events [45]. But market-based insurance has not been a significant instrument of risk mitigation and coping in most of Africa.

\subsection{The Ecosystem Approach to Aquaculture (EAA) and Risk/Impacts Management}

The ecosystem approach to aquaculture is a strategic approach to development and management of the sector aiming to integrate aquaculture within the wider ecosystem such that it promotes sustainability of interlinked social-ecological systems. An enabling environment is crucial to adopt the EAA. There is a need for an enabling framework for an ecosystem sustainable development approach facilitating different sectors and institutions to talk amongst each other and to promote coordinated actions (e.g., legislation, management measures, etc.).

This could be attained with the application of the EAA management. Incorporating EEA and risk/impacts management strategies into policy and development programmes; improving the capacities of institutions at the national, local and community levels for EEA application and risk/impacts management; and integrating the efforts of government, farmer groups, business and industry would increase collective resilience and likely provide ideas to find opportunities in the risks. These would give the aquaculture sector a much better ability to face external pressures [46].

\subsection{The Implications of Climate Change}

It represents best practice that should be pursued irrespective of climate change. Integrating disaster management into the fisheries sector, and vice versa, will be important, given the high vulnerability of the sector to extreme events. The suggested actions for way forward and mitigation are as follows: (1) ensure that the fisheries sector is clearly incorporated into mainstream climate change strategies and vice versa; (2) ensure that the opportunities and threats presented by climate change are understood and supported as part of adaptation measures for the sector; (3) identify and support high-risk coastal belt and locations; (4) build supportive economic and trade policies; (5) pursue appropriate technologies; (6) pursue mitigation actions in a manner that supports the sector more broadly [47].

\section{Evidence for Commercial Prospects}

Aquaculture production must increase to meet at least $50 \%$ of the global fisheries demand by the year 2030. The natural resources (aquatic and human resource) and potentials are endowed to Nigeria to propel aquaculture development and compete with Asian countries, like Japan. About 264 dams, with a cumulative capacity of 33 billion $\mathrm{m}^{3}$ of water can be utilized for cage-culture [13, 48]. According to Federal Department of Fisheries (FDF) [7], Nigerian coastline has huge potential for inland aquaculture and offshore cage culture. The maximum sustainable yield (MSY) of Nigerian marine water was observed by 
Table 3 Possible environmental/culture impacts of aquaculture.

\begin{tabular}{|c|c|c|c|}
\hline \multicolumn{2}{|c|}{ Culture system } & Environmental impact & System impact \\
\hline \multicolumn{4}{|c|}{ Extensive } \\
\hline 1 & Seaweed culture & $\begin{array}{l}\text { May occupy formerly pristine reefs; rough } \\
\text { weather losses. }\end{array}$ & $\begin{array}{l}\text { Weakening pond materials and } \\
\text { evaporation/dehydration; market } \\
\text { competition; conflicts/failures, } \\
\text { social disruption. }\end{array}$ \\
\hline 2 & $\begin{array}{l}\text { Coastal bivalve culture (mussels, oysters, } \\
\text { clams, cockles) }\end{array}$ & $\begin{array}{l}\text { Public health risks and consumer resistance } \\
\text { (microbial diseases, red tides, industrial } \\
\text { pollution); rough weather losses; seed } \\
\text { shortages. }\end{array}$ & $\begin{array}{l}\text { Shell cracks and low production, } \\
\text { market competition especially for } \\
\text { export produce; failures, social } \\
\text { disruption. }\end{array}$ \\
\hline 3 & $\begin{array}{l}\text { Coastal fishponds (mullets, milkfish, } \\
\text { shrimps, tilapias) }\end{array}$ & $\begin{array}{l}\text { Destruction of ecosystems, especially } \\
\text { mangroves; increasingly non-competitive } \\
\text { with more intensive systems; non-sustainable } \\
\text { with high population growth. }\end{array}$ & $\begin{array}{l}\text { Poor quality of producte; } \\
\text { conflicts/failures, social disruption. }\end{array}$ \\
\hline 4 & $\begin{array}{l}\text { Pen and cage culture in eutrophic waters } \\
\text { and/or rich benthos (carps, catfish, } \\
\text { milkfish tilapias) }\end{array}$ & $\begin{array}{l}\text { Exclusion of traditional fishermen; } \\
\text { navigational hazards. }\end{array}$ & $\begin{array}{l}\text { Poor quality of producte; conflicts, } \\
\text { social disruption; management } \\
\text { difficulties; wood consumption. }\end{array}$ \\
\hline \multicolumn{4}{|c|}{ Semi-intensive } \\
\hline 1 & $\begin{array}{l}\text { Fresh and brackish water pond (shrimps } \\
\text { and prawns, carps, catfish, milkfish, } \\
\text { mullets, tilapias) }\end{array}$ & $\begin{array}{l}\text { Fresh water: health risks to farm workers } \\
\text { from waterborne diseases; } \\
\text { Brackish water: salinization/acidification of } \\
\text { soils/aquifers. }\end{array}$ & $\begin{array}{l}\text { Both: market competition, } \\
\text { especially for export produce; feed } \\
\text { and fertilizer availability/prices; } \\
\text { conflicts/failures, social disruption; } \\
\text { poor quality of product and low } \\
\text { yield. }\end{array}$ \\
\hline 2 & $\begin{array}{l}\text { Integrated agriculture-aquaculture } \\
\text { (rice-fish; live stock/poultry-fish; } \\
\text { vegetables-fish and all combinations of } \\
\text { these) }\end{array}$ & $\begin{array}{l}\text { As freshwater above, plus possible consumer } \\
\text { resistance to excreta-fed produce; } \\
\text { competition from other users of inputs, such } \\
\text { as livestock excreta and cereal brans; toxic } \\
\text { substances in livestock feeds (eg., heavy } \\
\text { metals) may accumulate in pond sediments } \\
\text { and fish; pesticides may accumulate in fish. }\end{array}$ & $\begin{array}{l}\text { Poor quality of production and low } \\
\text { yield. }\end{array}$ \\
\hline 3 & $\begin{array}{l}\text { Sewage-fish culture (waste treatment } \\
\text { ponds; latrine wastes and septage used as } \\
\text { pond inputs; fish cages in wastewater } \\
\text { channels) }\end{array}$ & $\begin{array}{l}\text { Possible health risks to farm workers, fish } \\
\text { processors and consumers. }\end{array}$ & $\begin{array}{l}\text { Low palatability/poor quality of } \\
\text { produce and low yield, consumer } \\
\text { resistance to produce. }\end{array}$ \\
\hline 4 & $\begin{array}{l}\text { Cage and pen culture, especially in } \\
\text { eutrophic waters or on rich benthos } \\
\text { (carps, catfish, milkfish, tilapias) }\end{array}$ & As extensive cage and pen systems above. & $\begin{array}{l}\text { Occasional breakage of cage/pen } \\
\text { materials; consumer resistance to } \\
\text { produce. }\end{array}$ \\
\hline \multicolumn{4}{|c|}{ Intensive } \\
\hline 1 & $\begin{array}{l}\text { Freshwater, brackish water and marine } \\
\text { ponds (shrimps; fish, especially carnivores } \\
\text { — catfish, snakeheads, groupers, sea bass, } \\
\text { etc.) }\end{array}$ & $\begin{array}{l}\text { Effluents/drainage high in biological oxygen } \\
\text { demand (BOD) and suspended solids; market } \\
\text { competition, especially for export product. }\end{array}$ & $\begin{array}{l}\text { Occasional breakage of cage/pen } \\
\text { materials and facility faults; } \\
\text { conflicts/failures, social disruption. }\end{array}$ \\
\hline 2 & $\begin{array}{l}\text { Freshwater, brackish water and marine } \\
\text { cage and pen culture (finfish, especially } \\
\text { carnivores_-groupers, sea bass, etc., but } \\
\text { also some omnivores, such as common } \\
\text { carp) }\end{array}$ & $\begin{array}{l}\text { Accumulation of anoxic sediments below } \\
\text { cages due to fecal and waste feed build-up; } \\
\text { market competition, especially for export } \\
\text { produce. }\end{array}$ & $\begin{array}{l}\text { Occasional breakage of cage/pen } \\
\text { materials and facility faults, } \\
\text { conflicts/failures, social disruption; } \\
\text { consumption of wood and other } \\
\text { materials. }\end{array}$ \\
\hline 3 & Other—raceways, silos, tanks, etc. & $\begin{array}{l}\text { Effluents/drainage high in BOD and } \\
\text { suspended solids. }\end{array}$ & $\begin{array}{l}\text { Occasional breakage of cage/pen } \\
\text { materials; many location-specific } \\
\text { problems, facility faults. }\end{array}$ \\
\hline
\end{tabular}

Source: Modified from Pullin [45].

Ikenweiwe [49], who stated that Nigeria has about 853 $\mathrm{km}$ coastline and a maritime water of $210,900 \mathrm{~km}^{2}$ including the exclusive economic zone (EEZ). Nwosu et al. [50] and FAO [51] noted that the figures of coastline and marine water are about $900 \mathrm{~km}, 217,313$ $\mathrm{km}^{2}$ and $960 \mathrm{~km}, 309,120 \mathrm{~km}^{2}$, respectively. These together are evidence for commercial prospects for sustainable fish farming business in Nigeria. 
Commercial aquaculture increases the availability of food fish, especially in the coastal areas. It produces food fish for farm households who consume their own fish, and for domestic buyers who consume purchased fish as well [11]. Commercial aquaculture may also earn foreign exchange from exports that can be used to pay food import bills [7, 11]. Aquaculture is also a sector for the poor who have few alternatives and no resources. In Nigeria, aquaculture does not typically attract the wealthy who perceive aquaculture risks as high and financing difficult. The wealthy prefer offshore fishing and trading [7, 11]. Aquaculture therefore is attractive to policy-makers, because it absorbs the poor. Nigerian women play a predominant role as hired workers in semi-intensive operations. For all species, about $80 \%$ of workers involved in aquaculture processing are women. On the one hand, traditional farming would include carp/catfish and tilapia culture in most coastal waters, and most aquaculture operations are small-scale $[7,11$, 49, 51].

\section{Conclusions}

Aquaculture business is viable in Nigeria from all indications, but more effort is required from both the public and government to increase its local production and bridge the gap between the fish demand and supply in the country. Besides, the commonly cultured fresh water catfish in Nigeria, several marine shell and fin fish species can also be cultured in Nigeria, with the need for aquaculture to rise in terms of technological innovation and adaptation so as to meet changing and challenging requirements.

\section{Recommendation}

The Nigeria mariculture industry can be developed through innovative technology transfer between the aquaculture industries and research institutes/higher institution. This should reflect growth in terms of facilities, utilities and equipments that enable commercial production of aquatic organisms, throughout their life cycles and in captivity. This increased production may be feasible from scientific and technology advancement through a sustainable aquaculture system.

In rearing cultured fishes in the natural aquatic environment (mariculture), caution is needed because transfer of diseases is usually rife in densely populated stocks of fishes, and in addition, pollution of the ecosystem can result from feed remnant and alter water quality.

Also, the Nigeria macroalgae aquaculture industry can provide raw materials for other sectors of the economy, as well as the potential for bioremediation of both the atmospheric and aquatic environment.

\section{Acknowledgments}

Thanks to the Department of Biodiversity and Conservation Biology at the University of the Western Cape, South Africa and the Department of Agricultural Science at the Adeniran Ogunsanya College of Education, Lagos, Nigeria. Also appreciate the contribution and efforts of Mr. Lamina Arubiewe (lab technologist) at the Department of Agricultural Science, Adeniran Ogunsanya College of Education, Lagos, Nigeria.

\section{References}

[1] McHugh, D. J. 2003. "A Guide to the Seaweed Industry." FAO Fisheries Technical Paper No. 441, Rome. Accessed July, 2003. http://www.fao.org/3/a-y4765e.pdf.

[2] Food and Agriculture Organization of United Nations (FAO). 2009. The State of World Fisheries and Aquaculture 2008. Rome: FAO Fisheries and Aquaculture Department.

[3] Food and Agriculture Organization of the United Nations (FAO). 2012. The State of World Fisheries and Aquaculture 2012. Rome: FAO.

[4] FAO 2011. The State of World Fisheries and Aquaculture 2010. Rome: FAO Fisheries and Aquaculture Department.

[5] FAO. 2015. "FishStatJ-Software for Fishery Statistical Time Series." FAO Fisheries and Aquaculture Department, Rome. Accessed June 23, 2015. http://www.fao.org/fishery/statistics/software/fishstatj/en.

[6] Ayinla, O. A. 2007. "Analysis of Feeds and Fertilizers for Sustainable Aquaculture Development in Nigeria.” In 
Study and Analysis of Feeds and Fertilizers for Sustainable Aquaculture Development, edited by Hasan, M. R., Hecht, T., De Silva, S. S., and Tacon, A. G. J. Rome: FAO, 453-70.

[7] Akinrotimi, O. A., Abu, O. M. G., and Aranyo, A. A. 2011. "Environmental Friendly Aquaculture Key to Sustainable Fish Farming Development in Nigeria." Continental J. Fisheries and Aquatic Science 5 (2): 17-31.

[8] Miller, J. W., and Atanda, A. N. 2004. Inventory of Fish Farms in Nigeria. Aquaculture and Inland Fisheries Project (AIFP), National Special Programme for Food Security.

[9] McHugh, D. J. 2001. Prospects for Seaweed Production in Developing Countries. FAO Fisheries Circular No. 968 FIIU/C968 (En), FAO, Rome.

[10] Food and Agriculture Organization of the United Nations (FAO). 2000. "Information on Fisheries Management in the Federal Republic of Nigeria.” Accessed March, 2000. http://www.fao.org/fi/oldsite/FCP/en/nga/body.htm.

[11] Amosu, A. O. 1997. "Possible Aquaculture in Nigeria." B.Sc. thesis, Lagos State University, Ojo, Lagos.

[12] Masser, M. P., Rakocy, J., and Losordo, T. M. 1999. "Recirculating Aquaculture Tank Production Systems: Management of Recirculating Systems.” SRAC Publication No. 452, South Regional Aquaculture Centre. Accessed March, 1999. http://aqua.ucdavis.edu/DatabaseRoot/pdf/452RFS.PDF.

[13] Emmanuel, O., Chinenye, A., Oluwatobi, A., and Peter, K. 2014. "Review of Aquaculture Production and Management in Nigeria." American Journal of Experimental Agriculture 4 (10): 1137-51.

[14] Critchley, A. T. 1993. "Gracilaria (Rhodophyta: Gracilariales): An Economically Important Agarophyte.” In Seaweed Cultivation and Marine Ranching, edited by Ohno, M., and Critchley, A. T. Yokosuka, Japan: Japan International Cooperation Agency (JICA), 89-112.

[15] Amosu, A. O., Bashorun, O. W., Babalola, O. O., Olowu, R. A., and Togunde, K. A. 2012. "Impact of Climate Change and Anthropogenic Activities on Renewable Coastal Resources and Biodiversity in Nigeria.” Journal of Ecology and the Natural Environment 4 (8): 201-11.

[16] Amosu, A. O., Robertson-Andersson, D. V., Maneveldt, G. W., Anderson, R. J., and Bolton, J. J. 2013. "South African Seaweed Aquaculture: A Sustainable Development Example for Other African Coastal Countries.” Afr. J. Agri. Sci. 8 (43): 5260-71.

[17] Akinrotimi, O. A., Owhonda, K. N., and Ibemere, I. F. 2005. "Brackish Water Fish Farming: A Viable Options in Poverty Alleviations in Niger Delta." Presented at Fisheries Society of Nigeria (FISON) Conference, November 22-27, 2005, Port Harcourt, Nigeria.

[18] Deekae, S. N., Ayinla, O. A., and Marioghae, I. E. 1994.
Possibilities of the Culture of Mangrove Molluscs with Special Reference to the Niger Delta. Nigerian Institute for Oceanography and Marine Research (NIOMR) Technical Paper 96.

[19] Troell, M. D., Hecht, T., Beveridge, M., Stead, S., Bryceson, I., Kautsky, N., Mmochi, A., and Ollevier, F., eds. 2011. Mariculture in the WIO Region: Challenges and Prospects. Nairobi, Kenya: Kulgraphics Ltd.

[20] Coche, A. G., ed. 1982. Coastal Aquaculture: Development Perspectives in Africa and Case Studies from Other Regions. CIFA Technical Paper No. 9.

[21] Silvalingham, S. 1972. Fish Culture Possibilities around Lagos Lagoon and Results of Recent Trials. Federal Fisheries Occasional Paper.

[22] Ezenwa, B. O. I. 1975. "Fish Seed Production in Nigeria." CIFA Technical Paper No. 4, FAO, Rome.

[23] Ezenwa, B. O. I. 1979. "Supplementary Fish Feeding." NIOMR Occasional Paper No. 30.

[24] Food and Agricultural Organization of the United Nations. (FAO). 2016. The State of World Fisheries and Aquaculture 2016: Contributing to Food Security for All. Rome: FAO.

[25] John, D. M., and Lawson, G. W. 1997. "Seaweed Biodiversity in West Africa: A Criterion for Designating Marine Protected Areas." In The Coastal Zone of West Africa: Problems and Management, edited by Evans, S. M., Vanderpuye, C. J., and Armah, A. K. Sunderland, UK: Penshaw Press, 111-23.

[26] Fakoya, K. A., Owodeinde, F. G., Akintola, S. L., Adewolu, M. A., Abass, M. A., and Ndimele, P. E. 2011. “An Exposition on Potential Seaweed Resources for Exploitation, Culture and Utilization in West Africa: A Case Study of Nigeria.” J. Fish. Aquat. Sci. 6 (1): 37-47.

[27] Abowei, J. F. N., and Tawari, C. C. 2011. "A Review of the Biology, Culture, Exploitation and Utilization Potentials Seaweed Resources: Case Study in Nigeria.” Res. J. Appl. Sci. Eng. Technol. 3 (4): 290-303.

[28] Khan, S. I., and Satam, S. B. 2003. "Seaweed Mariculture. Scope and Potential in India.” Aquaculture Asia 8 (4): 26-9.

[29] Gupta, V., Kumar, M., Brahmbhatt, H., Reddy, C. R., Seth, A., and Jha, B. 2011. "Simultaneous Determination of Different Endogenetic Plant Growth Regulators in Common Green Seaweeds Using Dispersive Liquid-Liquid Microextraction Method.” Plant Physiol. Biochem. 49 (11): 1259-63.

[30] Chojnacka, K., Saeid, A., Witkowska, Z., and Tuhy, L. 2012. "Biologically Active Compounds in Seaweed Extracts-The Prospects for the Application.” The Open Conference Proceedings Journal 3: 20-8.

[31] Tuhy, L., Chowanska, J., and Chojnacka, K. 2013. "Seaweed Extracts as Bio-stimulants of Plant Growth: 
Review.” CHEMIK 67 (7): 636-41.

[32] Lewis, J., Salam, F., Slack, N., Winton, M., and Hobson, L. 2011. Product Options for the Processing of Marine Macroalgae.

[33] Hoppe, H. A. 1979. "Marine Algae and Their Products and Constituents in Pharmacy." In Marine Algae in Pharmaceutical Science, edited by Hoppe, H. A., Levring, T., and Tanaka, Y. Berlin: Water de Gruyter, 25-119.

[34] Tang, H. F., Yang-Hua, Y., Yao, X. S., Xu, Q. Z., Zhang, S. Y., and Lin, H. W. 2002. "Bioactive Steroids from the Brown Algae Sargassum carpophyllum.” J. Asian Nat. Prod. Res. 4 (2): 95-105.

[35] Robertson-Andersson, D. V. 2007. "Biological and economical Feasibility Studies of Using Seaweeds Ulva lactuca (Chlorophyta) in Recirculation Systems in Abalone Farming.” Ph.D. dissertation, University of Cape Town, South Africa.

[36] Kim, K. N., Ham, Y. M., Moon, J. Y., Kim, M. J., Kim, D. S., Lee, W. J., Lee, N. H., and Hyun, C. G. 2009. “In Vitro Cytotoxic Activity of Sargassum thunbergii and Dictyopteris divaricata (Jeju Seaweeds) on the HL-60 Tumour Cell Line.” Int. J. Pharmacol. 5 (5): 298-306.

[37] Eluvakkal, T., Sivakumar, S. R., and Arunkumar, K. 2010. "Fucoidan in Some Indian Brown Seaweeds Found along the Coast Gulf of Mannar.” Int. J. Bot. 6: 176-81.

[38] Amosu, A. O. 2016. "Using the Alga Ulva (Chlorophyta) for the Production of Biomethane and Mitigating against Coastal Acidification.” Ph.D. thesis, University of the Western Cape, South Africa.

[39] Amosu, A. O., Robertson-Andersson, D. V., and Maneveldt, G. W. 2015. "Seaweed Mariculture Provides Feed, Green Energy Production, Bioremediation.” Global Aquaculture Advocate 18 (2): 66-8.

[40] Amosu, A. O., Robertson-Andersson, D. V., Kean, E., Maneveldt, G. W., and Cyster, L. 2016. "Biofiltering and Uptake of Dissolved Nutrients by Ulva armoricana (Chlorophyta) in a Land-Based Aquaculture System.” Int. J. Agri. Biology 18 (2): 298-304.

[41] Nett Technologies Inc. 2012. "Fact Sheet: Catalytic Mufflers for LPG Engines.” Accessed April 2014. http://www.nettinc.com/docs/nett_factsheet_lpg_catalytic _mufflers.pdf.

[42] Amosu, A. O., Robertson-Andersson, D. V., Kean, E., and Maneveldt, G. W. 2014. "Aquaculture Benefits of Macroalgae for Green Energy Production and Climate Change Mitigation.” Int. J. Sci. Eng. Res. 5 (7): 146-52.

[43] Robertson-Andersson, D. V., Maneveldt, G. W., and Naidoo, K. 2011. "Effects of Wild and Farm-Grown Macroalgae on the Growth of Juvenile South African Abalone Haliotis midae (Linnaeus).” African Journal of Aquatic Science 36 (3): 331-7.

[44] Cyrus, M. D., Bolton, J. J., De Wet, L., and Macey, B. M. 2014. "The Development of a Formulated Feed Containing Ulva (Chlorophyta) to Promote Rapid Growth and Enhanced Production of High Quality Roe in the Sea Urchin Tripneustes gratilla (Linnaeus).” Aquaculture Research 45 (1): 159-76.

[45] Pullin, R. S. V. 1989. "Third World Aquaculture and the Environment.” The ICLARM Quarterly, January 1989.

[46] Secretan, P. A. D., Bueno, P. B., Van Anrooy, R., Siar, S. V., Olofsson, Å., Bondad-Reantaso, M. G., and Funge-Smith, S. 2007. Guidelines to Meet Insurance and Other Risk Management Needs in Developing Aquaculture in Asia. FAO Fisheries Technical Paper No. 496.

[47] FAO/Network of Aquaculture Centres in Asia-Pacific (NACA). 2011. Regional Review on Status and Trends in Aquaculture Development in Asia-Pacific 2010. FAO Fisheries and Aquaculture Circular No. 1061/5.

[48] Ukuedojor, M. 2013. "Adequate Drinking Water Still a Tall Dream in Nigeria.” Nigerian Daily Trust, January 5.

[49] Ikenweiwe, B. N. 2013. "Lecture Note on FIS 318: Fisheries Stock Assessment (2 Units).” Department of Aquaculture and Fisheries Management, University of Agriculture Abeokuta, Nigeria. Accessed on December 7, 2013. https://www.unaab.edu.ng/attachments/463_FIS318 \%20by\%20ITO.pdf.

[50] Nwosu, F. M., Ita, E. O., and Enin, U. I. 2011. "Fisheries Management in Nigeria: A Case Study of the Marine Fisheries Policy.” Int. Res. J. Agri. Sci. Soil Sci. 1 (3): 70-6.

[51] Food and Agriculture Organization of the United Nation (FAO). 2009. FishStatJ: Universal Software for Fishery Statistical Time Series. Version 23. Rome, Italy: FAO. 